\title{
Acoustic signals of the bush-crickets of tribe Barbitistini (Orthoptera: Tettigoniidae: Phaneropterinae) from Eastern Europe and Caucasus. II. Leptophyes Fieber, 1853, Euconocercus Bey-Bienko, 1950, Barbitistes Charpentier, 1825, Polysarcus Fieber, 1853
}

\section{Акустические сигналы кузнечиков трибы Barbitistini (Orthoptera: Tettigoniidae: Phaneropterinae) восточной Европы и Кавказа. II. Leptopbyes Fieber, 1853, Euconocercus Bey-Bienko, 1950, Barbitistes Charpentier, 1825, Polysarcus Fieber, 1853}

\author{
R.D. Zhantiev, O.S. Korsunovskaya \\ P.А. Жантиев, О.С. Корсуновская
}

\begin{abstract}
Department of Entomology, Moscow Lomonosov State University, Moscow 119992, Leninskie Gory, Russia. E-mail: zhantiev@mail.ru Кафедра энтомологии Московского государственного университета им. М.В.Ломоносова, Москва 119992, Ленинские горы, Россия.
\end{abstract}

KEY WORDS. Tettigoniidae, Barbitistini, Leptophyes, Euconocercus, Barbitistes, Polysarcus, acoustic signals.

КЛЮЧЕВЫЕ СЛОВА. Tettigoniidae, Barbitistini, Leptophyes, Euconocercus, Barbitistes, Polysarcus, акустические сигналы.

ABSTRACT. Temporal pattern and frequency spectra of the songs and stridulatory files of species belonging to genera of Leptophyes, Euconocercus, Barbitistes and Polysarcus of phaneropterine bush-crickets of the tribe Barbitistini from Eastern Europe and Caucasus are given. Acoustic signals of eastern European and Caucasian species with other European species of Barbitistes, Polysarcus and Leptophyes are compared.

РЕЗЮМЕ. Приводятся данные об амплитудновременных и частотных характеристиках звуковых сигналов и стридуляционных жилках листовых кузнечиков трибы Barbitistini из родов Leptophyes, Euconocercus, Barbitistes и Polysarcus из Восточной Европы и с Кавказа. Проводится сравнение их сигналов со звуками других европейских видов.

Phaneropterinae including more than 2000 species is the largest subfamily of Tettigoniidae. Sometimes this taxon is considered as family. Most of species are distributed in the Palaearctic. The high biodiversity of these bush-crickets is observed in the Mediterranean region. Males of all known Phaneropterinae species produce calling songs and females in many species are capable to respond with sounds. The results of the first investigations of acoustic communication of the palaearctic species were published in 1977-1981 [Zhantiev \& Dubrovin, 1977; Zhantiev, 1981]. Since then acoustic signals of many Mediterranean species are carefully studied [e.g. Heller, 1988; Heller, 1990; Ragge, Reynolds, 1998; Sevgili et al., 2010; Chobanov et al.,
2013], but songs of species from the South of the East Europe, Caucasus and Transcaucasia are less known. Sound signals of only a few phaneropterine bush-crickets are described [op. cit.; Zhantiev, Korsunovskaya, 1986, 1990, Korsunovskaya, 2015]. We suppose that it is interesting and useful to compare the comprehensive studied songs of specimens from West European populations (e.g. Leptophyes albovittata (Kollar, 1833) and Barbitistes constrictus Brunner von Wattenwyl, 1878) with corresponding data concerning eastern European specimens of these species. Songs of Euconocercus iris Bey-Bienko, 1950 and Polysarcus zacharovi (Stshelkanovtzev, 1910) were investigated at the first.

\section{Material and methods}

Laboratory tape-recordings of the songs of captured insects were made with use 1/4 inch Bruel\&Kjaer 4135 or MK 301 RFT microphones with linear characteristics in the range $0.02-100 \mathrm{kHz}$, microphone ampliphier 2604 Bruel\&Kjaer or 00017 RFT and modified tape recorder "Yupiter-202 Stereo" with linear characteristic in the range $0.063-70 \mathrm{kHz}$. Songs of several species were recorded with the use of the mentioned microphone amplifiers connected with A-D converter E14440 (L-card, Russia) of computer. Most of songs were stored on magnetic tape and then were digitized (sampling rate are $30.3 ; 58.8 ; 142.8$ or $200 \mathrm{kHz}$ ) and analyzed using the computer program TurboLab 2.4. All power spectra were obtained with linear amplitude scale. 
All laboratory experiments were made in anechoic chamber in darkness at $22-27^{\circ} \mathrm{C}$. Microphone was positioned at $8-10 \mathrm{~cm}$ of singing male. Recordists O.Korsunovskaya and R.Zhantiev.

Electronograms of stridulatory files (pars stridens) were obtained by use of scanning electron microscopes S-405A and CamScan S-2.

\section{Terminology}

For the description of songs the following terminology is used:

pulse - sound produced by closing forewing-strokes at stridulation [= hemisyllable of Ragge \& Reynolds, 1998; Heller et al., 2004];

series [= echemes of Ragge \& Reynolds, 1998] the first order assemblage of pulses;

click - very fast sound impulse sometimes following pulse. In some species it is the obligatory second component of the song.

tooth-impact [= impulse of Heller et al., 2004] fast sound impulse arising during contact of single tooth of pars stridens with plectrum.

\section{Results and discussion}

\section{Leptophyes albovittata (Kollar, 1833)}

Distribution area of this species is much wider than that of other congenerics [Kleukers et al., 2010]. Now is known that only L. albovittata occurs in Eastern part of Europe and Caucasus.

LOCALITIES: Transcarpatian: Uzhgorod distr., vil. Vyshka; Central Russia, Kursk distr.: Centralno-Chernozemny reserve.; Ciscaucasia, near Grozny.

SONG. Males produce calling song (Figs 1-2, 5) and perhaps aggressive ones (Figs 1-4) when two males are nearby. Females respond to male sounds by short click and stay at the same position as long as male finds it after her sound response. The selectivity of female reaction is low, any relatively short sound is able to elicit female click. It should be noted that the beginning of the male song causes the reply [Zhantiev, Korsunovskaya, 1986].

Calling song of the Eastern European specimens represented by a short pulse containing up to 19 toothimpacts (Figs 2-3). Sometimes males are able to produce more short sounds with 4-11 tooth-impacts. Such pulses were observed when one male is positioned at the second one (Figs 2-4) and perhaps these sounds can function as an aggressive signal. In some populations male produce two-component song consisting of a simple sound pulse and one (rare two) clicks. The last ones can have different amplitude - very low (Fig. 5) or comparable with main pulse. K.-G. Heller [1988] noticed that very rare in the song of Western European specimens there is distinguishable crescendo series of weak tooth-impacts following the pulse. Such final series in Eastern European and Ciscaucasian specimens did not observed. Duration of the pulse in different studied population is very similar:
$27.0 \pm 0.5 \mathrm{~ms}\left(22^{\circ} \mathrm{C}, \mathrm{SD}=2.0\right.$; Transcarpatian specimen $)$ and $\overline{2} 8 \pm 3 \mathrm{~ms}\left(\mathrm{SD}=11.4,27^{\circ} \mathrm{C}\right.$, Kursk specimen). Pause between pulse and click if present in male song lasts $30.3 \pm 0.8 \mathrm{~ms}\left(\mathrm{SD}=3.2,22^{\circ} \mathrm{C}\right.$, Transcarpatian specimen) and $\overline{3} .3$ to $15 \mathrm{~ms}$ (Kursk population, $27^{\circ} \mathrm{C}$ ). Calling songs of other European congenerics as Leptophyes punctatissima (Bosc, 1792), L. boscii Fieber, 1853 and L. discoidalis (Frivaldszky, 1868) have optional clicks after main fast pulse too [Heller, 1988].

Spectrum of male sounds lies in the band 30-80 $\mathrm{kHz}$. Main peak is near $50 \mathrm{kHz}$. In some spectra are distinguishable additional periodical peaks (Figs 6-7)

Male pars stridens (Fig. 8) contains ca. 60 teeth.

\section{Euconocercus iris Bey-Bienko, 1950}

This Caucasian genus is very similar to Leptophyes Fieber, 1853 but differs from it by form of base of male cerci and strongly sharpened and elongated genital plate of female.

Only two species in the genus is known. Euconocercus caucasicus Bey-Bienko, 1950 occurs in Ciscaucasia (Daghestan), Northern Caucasus (Essentuki), Transcaucasia (Armenia); E. iris distributed in SE Azerbaidjan (Lenkoran distr.). The last species is known as a pest subtropical crops.

LOCALITY. Males and females were collected in Azerbaidjan, Lenkoran distr., vil. Lerik.

SONG. Males produce two kinds of sounds. The first one is the calling song. It is represented by series followed by one or two clicks (Figs 9-11). Pause between two parts of the song is $111 \pm 3 \mathrm{~ms}(\mathrm{SD}=9.8)$. Each series lasts about 1.4-3 s depending on number of pulses. In our records series contain 30-60 pulses. Calling signals in our experiments were produced irregular or in low rate about $0.1-0.2 \mathrm{~s}^{-1}$. Pulses last $15-27 \mathrm{~ms}$ (mean 20.4+0.5 $\mathrm{ms}, \mathrm{SD}=2.6$ ), intervals between them $24.2 \pm 0.5 \mathrm{~ms}$, $\mathrm{SD}=2.7$. Period of pulses increases from the beginning to the end of series from $40 \mathrm{~ms}$ to more than $70 \mathrm{~ms}$ (mean is $54.4 \pm 0.6 \mathrm{~ms}, \mathrm{SD}=5.8$ ). Pulses in the first part of the song consist of 3 to 5-6 tooth-impacts. Second part of the song (clicks) acts as a trigger for female sound reply, rare females respond after the first part of the song.

Males during contact with another male produce a song of the second type. These sounds indicate antagonistic relations between males and can be qualified as agressive (or territorial) signals. As a rule these sounds are a pairs (series) of pulses with irregular or more rare regular (with rate about $0.5 \mathrm{~s}^{-1}$ ) intervals between series (Fig. 12). Duration of pulses is $24.6 \pm 0.4 \mathrm{~ms}(\mathrm{SD}=3.4)$, intervals between pulses last $46.6 \pm 0.8 \mathrm{~ms}(\mathrm{SD}=4.3)$. Periods of tooth-impacts in the pulses of two kind of song are $5.0 \pm 0.1 \mathrm{~ms}$ and $6.2 \pm 0.2 \mathrm{~ms}, \mathrm{SD}=1.2$ and 1.6 respectively.

Spectra of the calling song (Fig. 13) and the song of the second type are almost identical - main high frequency components lie in the band $20-40 \mathrm{kHz}$ with dominant amplitudes near $30 \mathrm{kHz}$.

Stridulatory file is weakly curved and contains numerous teeth of exponentially decreasing size and density to the medial edge (Fig. 14). 

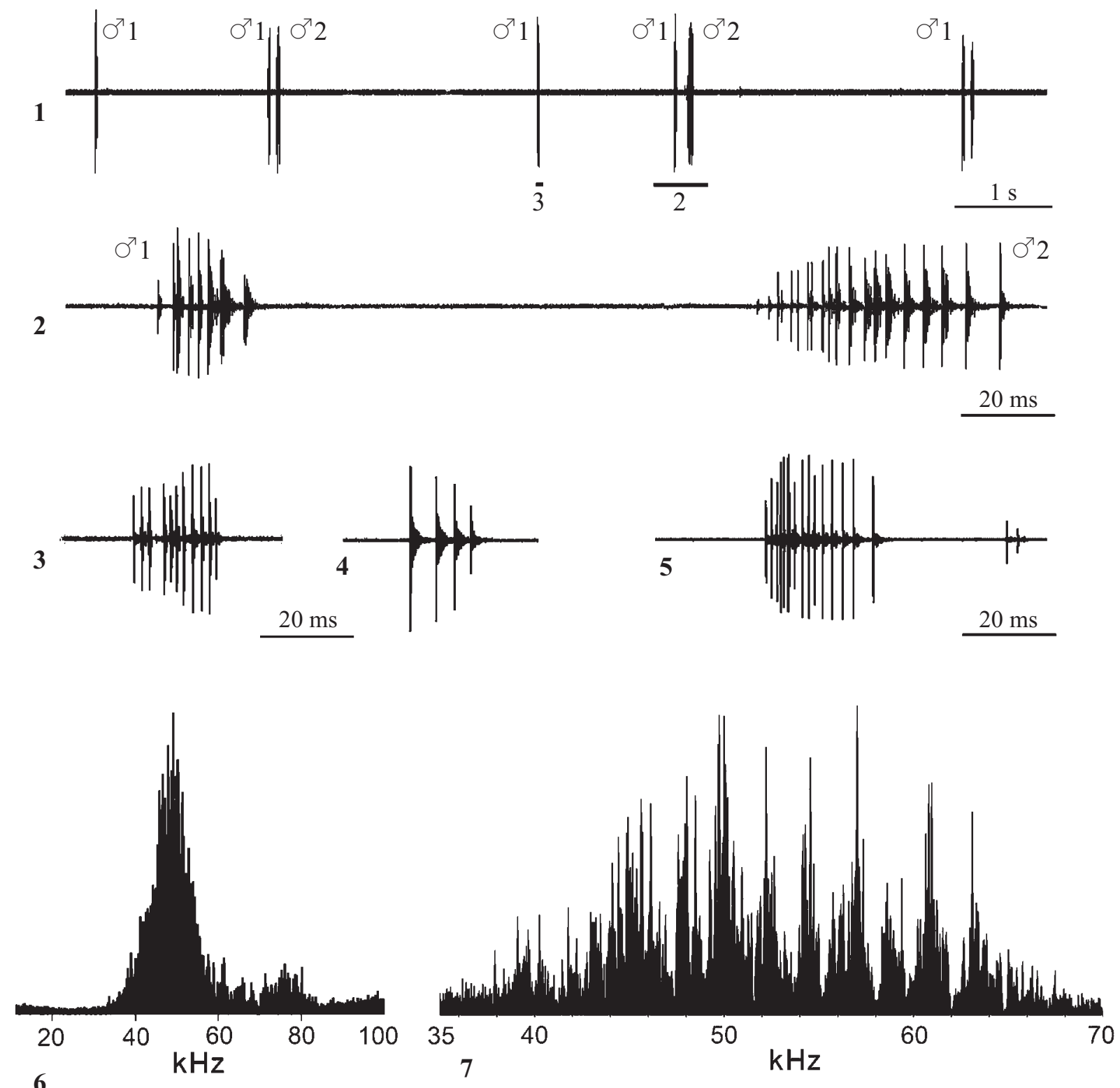

8

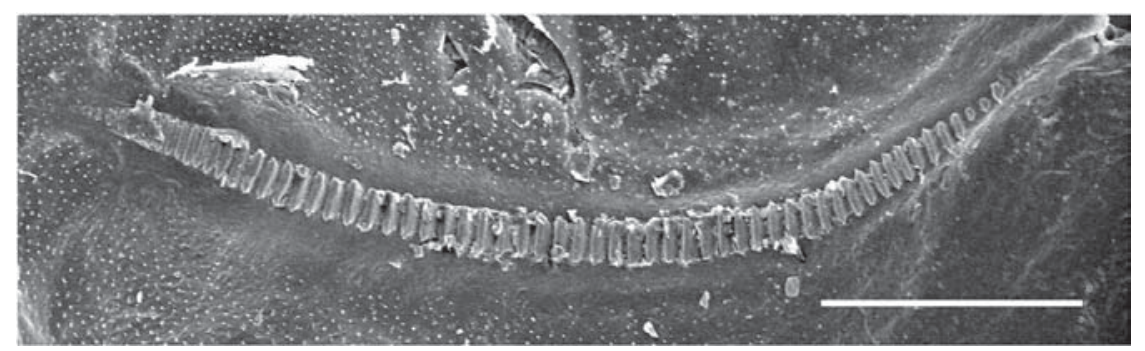

Figs 1-8. Leptophyes albovittata: $1-5$ - oscillogrms of a male songs at different velocities; $6-7$ - frequency spectrum of calling song in linear scale; $1-3$ - sounds of two alternatively stridulating males $\left(27^{\circ} \mathrm{C}, \mathrm{Kursk}\right.$ distr. $) ; 4$ - aggressive sound of a male $\left(22^{\circ} \mathrm{C}\right.$, Kursk distr.); $5-6$ - calling song $\left(22^{\circ} \mathrm{C}\right.$, Uzhgorod distr); 8 - male stridulatory file (scale $\left.400 \mu \mathrm{m}\right)$.

Рис. 1-8. Leptophyes albovittata: 1-5 - осциллограммы акустических сигналов самцов при разных скоростях развёртки; 6-7амплитудно-частотный спектр призывного сигнала; $1-3-$ звуки двух альтернирующих самцов $\left(27^{\circ} \mathrm{C}\right.$, окр. Курска); $4-3 в у к$ агрессии самца $\left(22^{\circ} \mathrm{C}\right.$, окр. Курска); 5-6 - призывный сигнал $\left(22^{\circ} \mathrm{C}\right.$, окр. Ужгорода); 8 - стридуляционная жилка самца (масштаб 400 мкм). 

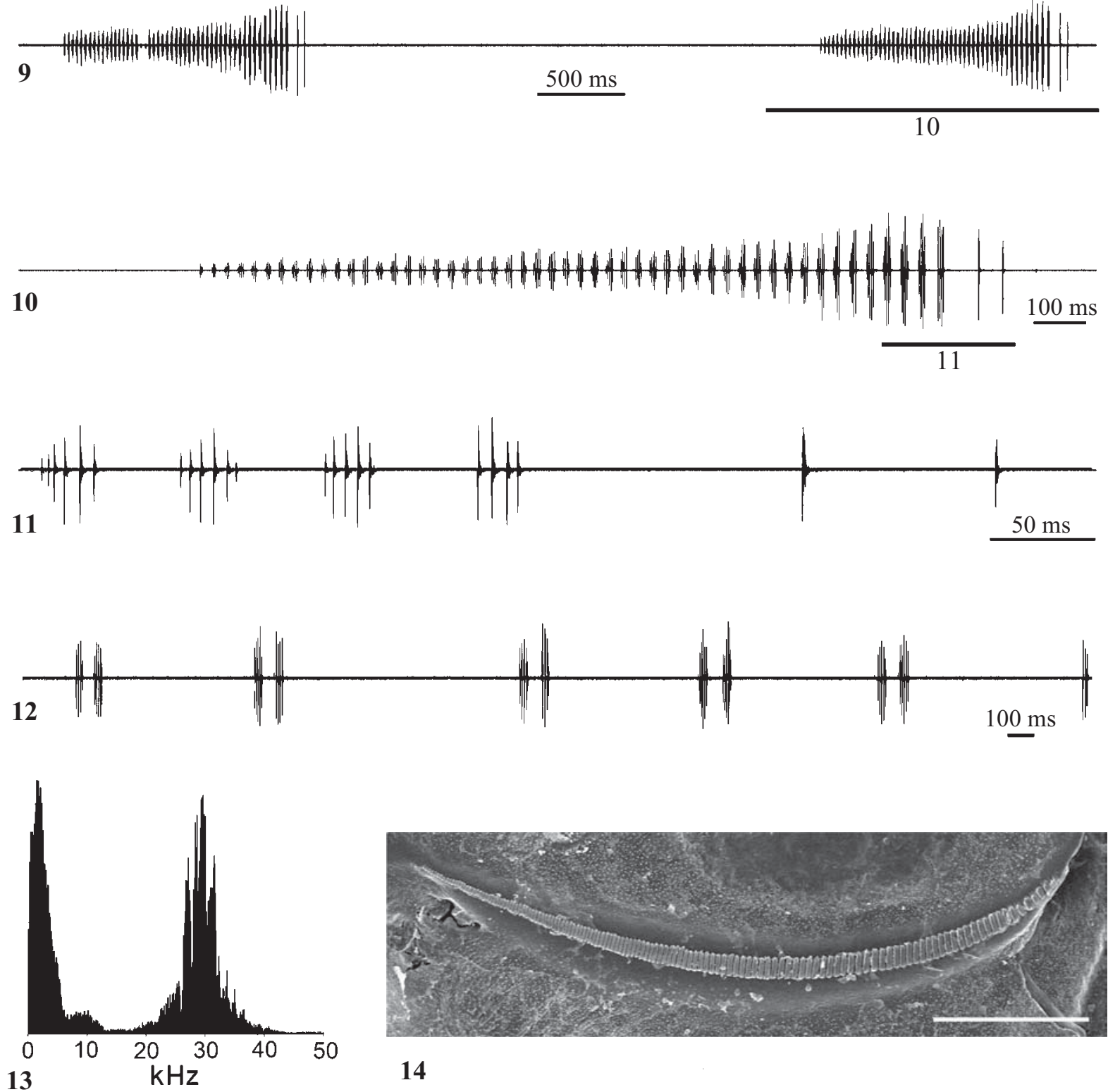

14

Figs 9-14. Euconocercus iris: 9-11 - oscillograms of male calling song at different velocities, $24^{\circ} \mathrm{C} ; 12$ - oscillogram of male aggressive sounds at $24^{\circ} \mathrm{C} ; 13$ - frequency spectrum of the male calling song; 14 - stridulatory file of the male (scale $400 \mu \mathrm{m}$ ).

Рис. 9-14. Euconocercus iris: 9-11 - осциллограммы призывного сигнала самца при разных скоростях развёртки, $24^{\circ} \mathrm{C} ; 12-$ осциллограмма сигнала агрессии самца при $24^{\circ} \mathrm{C} ; 13$ - амплитудно-частотный спектр призывного сигнала самца; 14 стридуляционная жилка самца (масштаб 400 мкм)

\section{Barbitistes constrictus}

Brunner von Wattenwyl, 1878

This species is distributed in Central and Eastern Europe up to Leningrad and Novgorod vicinities in the North.

LOCALITIES. Central Russia, near Moscow: vil. Iljinskoe; vil. Novy Ierusalim.

SONG of males is represented by sequence of 6-14 fast pulses and loud one or two final clicks following after pause of $772 \pm 12 \mathrm{~ms}(\mathrm{SD}=40.5)$ (Figs 15-17). Sometimes after this click there are one or two weak tooth-impacts. Similar temporal pattern is observed in two other European species: Barbitistes ocskayi (Charpentier, 1850) and B. yersini Brunner von Wattenwyl, 1878 [Heller, 1988; Stumpner, Meyer, 2001]. In B. constrictus of Moscow vicinity duration of pulses in the series is $4-8 \mathrm{~ms}$, final click lasts $10-12 \mathrm{~ms}$, period of the pulses in main part of the series is $115 \pm 2 \mathrm{~ms}$ $(\mathrm{SD}=18.8)$, duration of the whole signal is about $2.5 \mathrm{~s}$, repeating rate is about $0.3 \mathrm{~s}^{-1}$ at $23^{\circ} \mathrm{C}$.

In male calling song main components of the frequency spectrum lie in the band between 10 and $35 \mathrm{kHz}$. Dominant frequencies of the pulses in the series can 


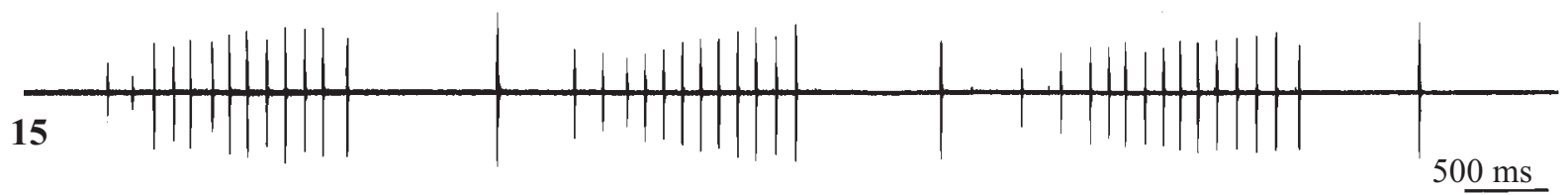

16

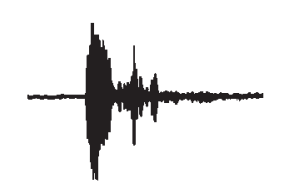

17

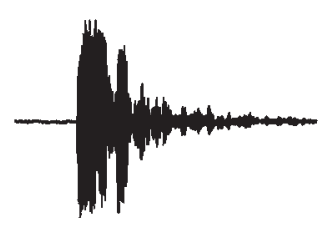

$10 \mathrm{~ms}$
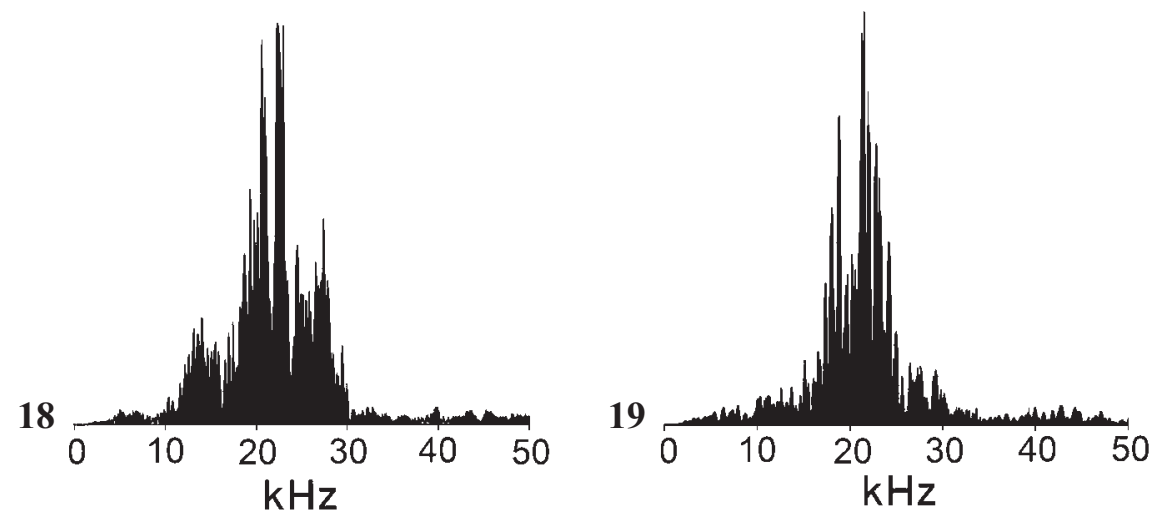

Figs 15-19. Barbitistes constrictus: $15-17$ - oscillograms of male calling song of at different velocities, $23^{\circ} \mathrm{C}$; $18-19-$ frequency spectrum; 15 - three series with final clicks; 16 - one of the pulses of the $1^{\text {st }}$ component of the song; 17 -click after series $\left(2^{\text {nd }}\right.$ component of the song); 18 - pulses from series of calling song; 19 - click after series of calling song.

Рис. 15-19. Barbitistes constrictus: 15-17 - осциллограммы призывного сигнала самца при разных скоростях развёртки, $23^{\circ} \mathrm{C}$; 18-19 - амплитудно-частотный спектр; 15 - три серии с заключительными щелчками; 16 - один из пульсов I компонента сигнала; 17 - заключительный щелчок (II компонент сигнала); 18 - пульсы из серии призывного сигнала; $19-$ щелчок после серии призывного сигнала.

slightly shift from 18 to $24 \mathrm{kHz}$. There are some additional peaks at 14 or $19 \mathrm{kHz}$ (Figs 18-19). These data coincides with frequency spectra of Serbian specimens [Stumpner, Meyer, 2001].

Male pars stridens (Figs 20-21) is almost straight in the lateral and middle part of tegmen and curved to its medial edge. Number of teeth is ca. 70. Shape, size and density of most teeth are almost uniform besides some medial and lateral ones.

Female stridulatory apparatus contains 4 main files with dense teeth and 3-4 veins with more rare teeth in the basal and apical end of the upper part of the lower tegmen (Figs 22-23). The plectrum lies on the underside part of the upper tegmen (Figs 24-25).

Earlier the song of $B$. constrictus specimens was described by Zhantiev \& Korsunovskaya [1986] and Heller [1988]. Stumpner and Meyer [2001] worked with specimens reared in laboratory (the origin of insects is not specified). Therefore we can compare the songs of the German (Mittelfranken, Muggendorf) and Eastern European specimens only. Their calling sounds are very similar and differences are only in the number of pulses in the first part of the series. In western specimens this song fragment contains $8-10$ pulses and eastern ones - 6-14 pulses. This parameter of male song of Western European specimens reared in a laboratory is up to 15. Data of sound recording of Ukrainian (Kanev) males (recordist K.-G. Heller, database DORSA, tape no. S1/1996A) show that they produce calling song with almost identical to Russian specimens temporal parameters. So number of the pulses in the series is more variable character.

\section{Polysarcus zacharovi (Stshelkanovtsev, 1910)}

It is one of five known species. Distributed in eastern Ciscaucasia, Caucasus, Transcaucasia, North-Eastern Turkey.

Known outbreaks of this species and correspondingly gregarious and solitary forms. Gregarious form is mostly dark (sometimes almost black) and smaller. During outbreaks $P$. zacharovi can damage mountine pastures and some agricultural crops [Avakian, 1981].

LOCALITY: Northern Ossetia, Northern Ossetian reserve.

SONG. Males produce very complicated calling sounds (Figs 26-33). That divides into three different alternating parts. The first one is the sequence of the fast pulses. They follow with regular rate (mean period is $42.7 \pm 0.2 \mathrm{~ms}, \mathrm{SD}=1.4$ ) and have duration $36.9 \pm 0.2 \mathrm{~ms}$ $(\mathrm{SD}=1.5)$. The second song fragment lasts about 3-4 s That is a sequence of series (of 10-20 pulses) alternating with separate single long pulses. Duration of the fast pulses is $34.7 \pm 0.3 \mathrm{~ms}(\mathrm{SD}=2.2)$, the slow pulses last $116.2 \pm 1.8 \mathrm{~ms}(\mathrm{SD}=8)$. Tooth-impacts rates in the pulses from series and the single ones differ. The third phase of calling song is more loud than the $1^{\text {st }}$ and $2^{\text {nd }}$ parts. It consists of double pulses repeating with period 51.5 \pm 0.3 $\mathrm{ms}(\mathrm{SD}=1.4)$. Mean duration of these pulses is $31.6 \pm 0.3$ $\mathrm{ms}(\mathrm{SD}=2.3)$. Definite sequence of different phases in the calling song is absent. Male is able to produce any part of the signal after a silent interval. However males at the initiation of singing as a rule produce calling song in described sequence of its parts.

Temporal pattern of this song is very similar to that of Polysarcus denticauda (Charpentier, 1825) described 

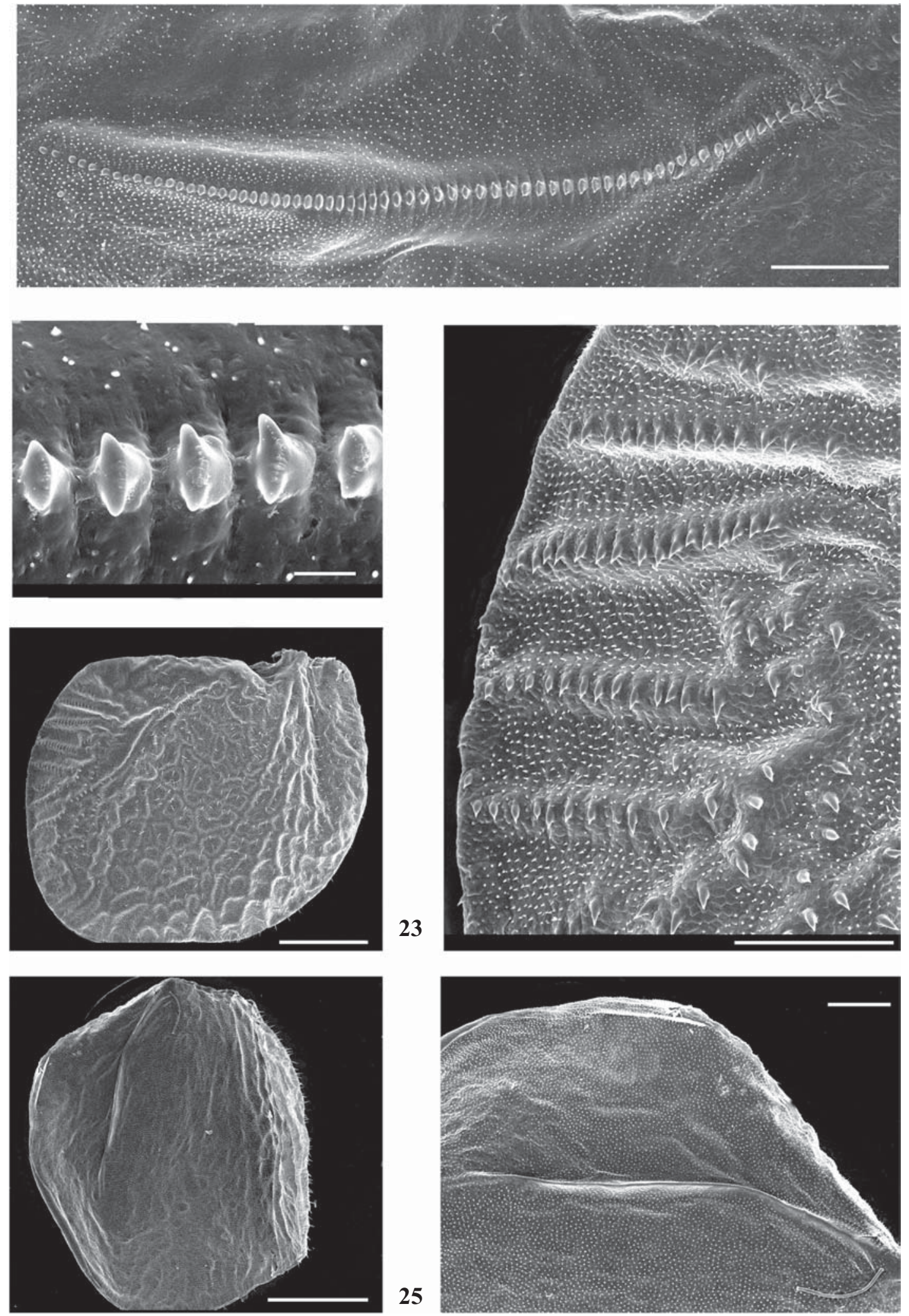

Figs 20-25. Barbitistes constrictus: 20-21 - male stridulatory file; 22 - female right tegmen; 23 - medial veins on the upper surface of the female right tegmen; 24 - female left tegmen with plectrum on the downer surface; 25 - plectrum on the female left tegmen. Scale bars: $20,23,25-300 \mu \mathrm{m} ; 21-30 \mu \mathrm{m} ; 22,24-1 \mathrm{~mm}$.

Pис. 20-25. Barbitistes constrictus: 20-21 - стридуляционная жилка самца; 22 - правое надкрылье самки; 23 - медиальные жилки на верхней поверхности правого надкрылья самки; 24 левое надкрылье самки с плектрумом на нижней поверхности; $25-$ плектрум на левом надкрылье самки. Масштаб: 20, 23, 25 - 300 мкм; $21-30$ мкм; 22, $24-1$ мм. 
26

I

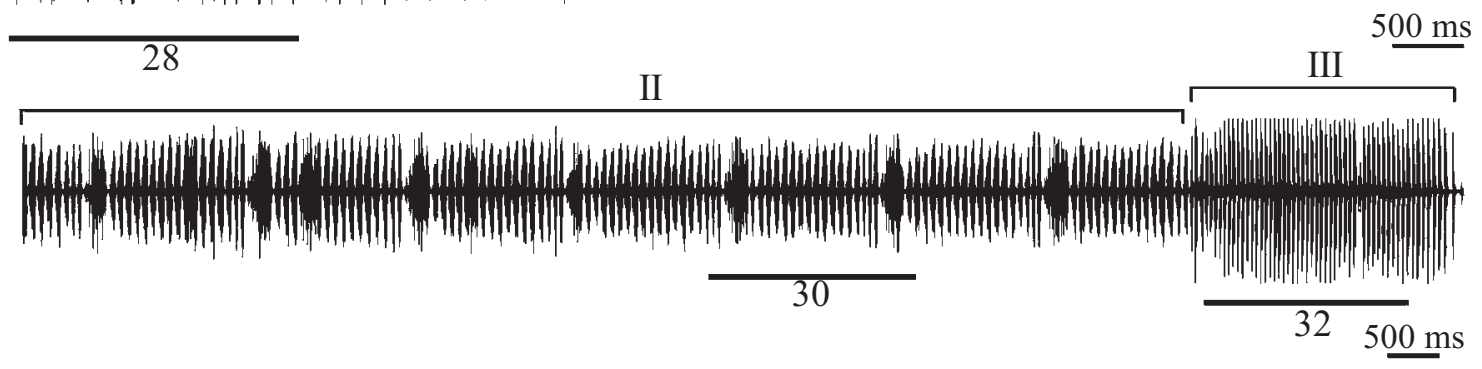

28

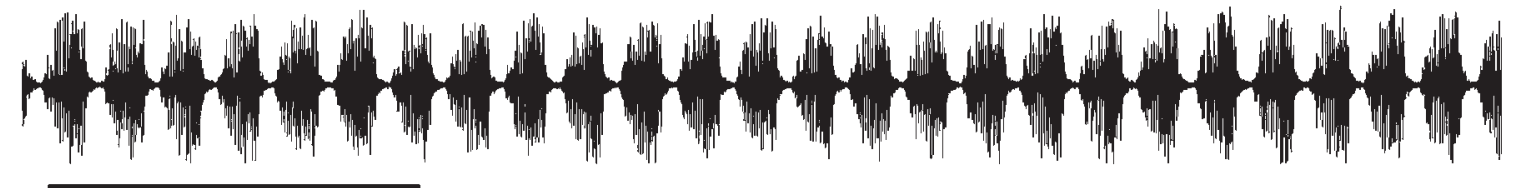

29

$100 \mathrm{~ms}$

29

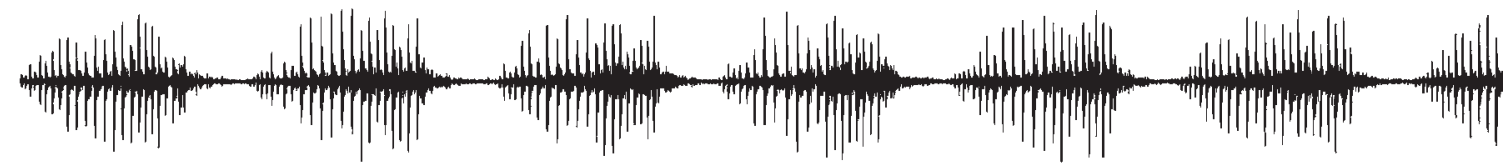

$50 \mathrm{~ms}$

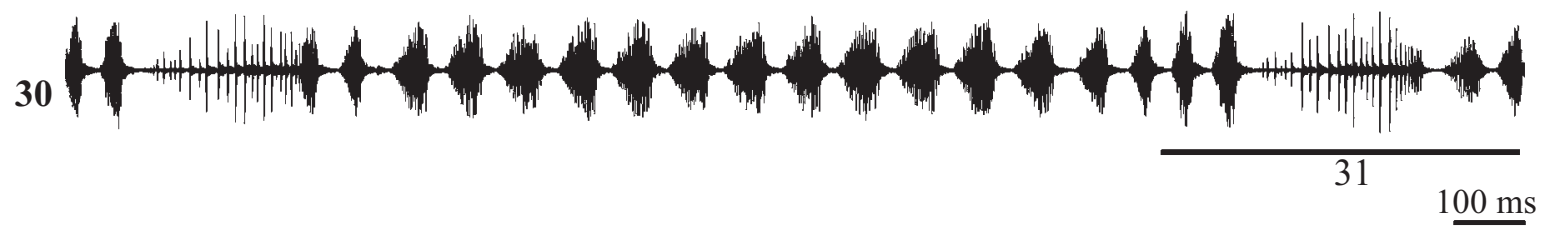

31

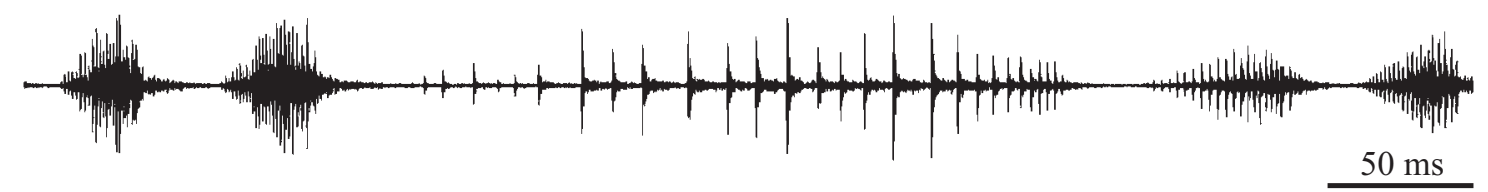

s

$100 \mathrm{~ms}$

33

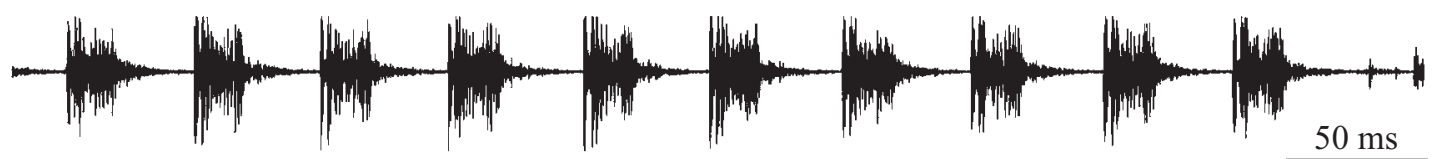

Figs 26-33. Oscillograms of calling song of male Polysarcus zacharovi at different velocities, $27^{\circ} \mathrm{C}$.

Рис. 26-33. Осциллограммы призывного сигнала самца Polysarcus zacharovi при разных скоростях развёртки, $27^{\circ} \mathrm{C}$. 


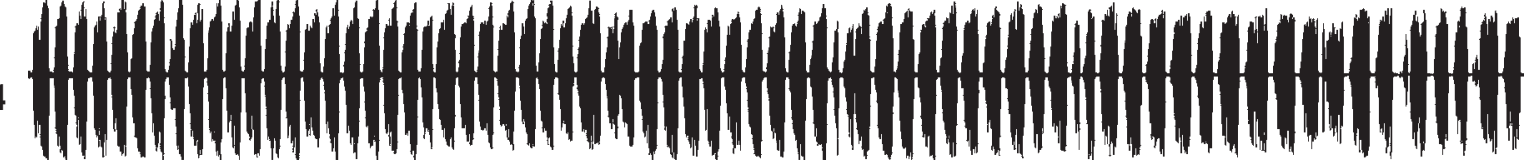

$500 \mathrm{~ms}$
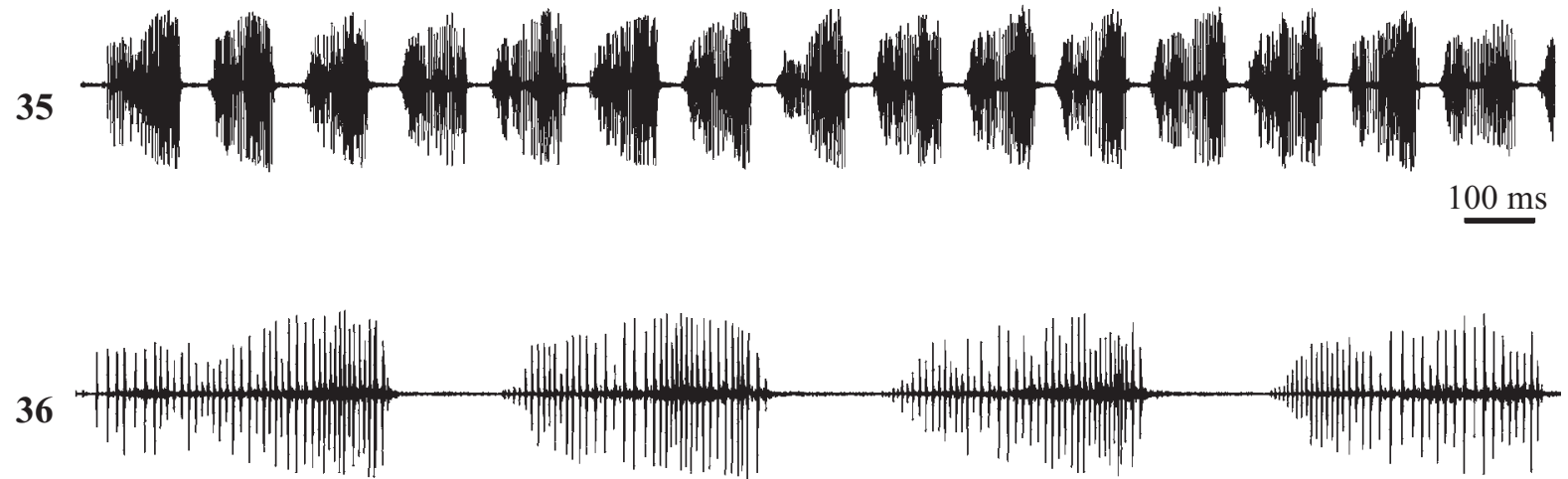

Figs 34-36. Oscillograms of protest sounds of male Polysarcus zacharovi at different velocities, $27^{\circ} \mathrm{C}$

Рис. 34-36. Осциллограммы сигнала протеста самца Polysarcus zacharovi при разных скоростях развёртки, $27^{\circ} \mathrm{C}$.

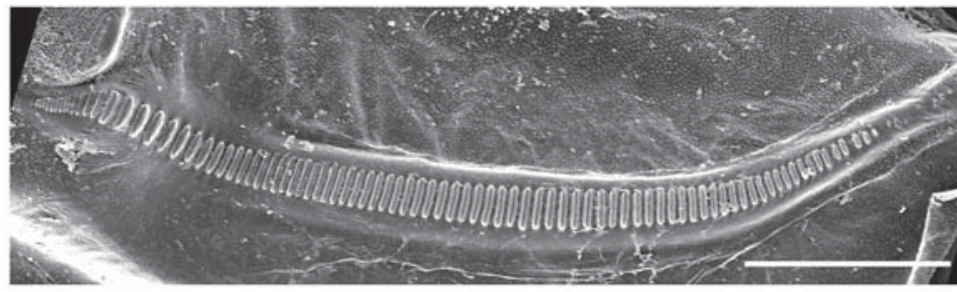

41
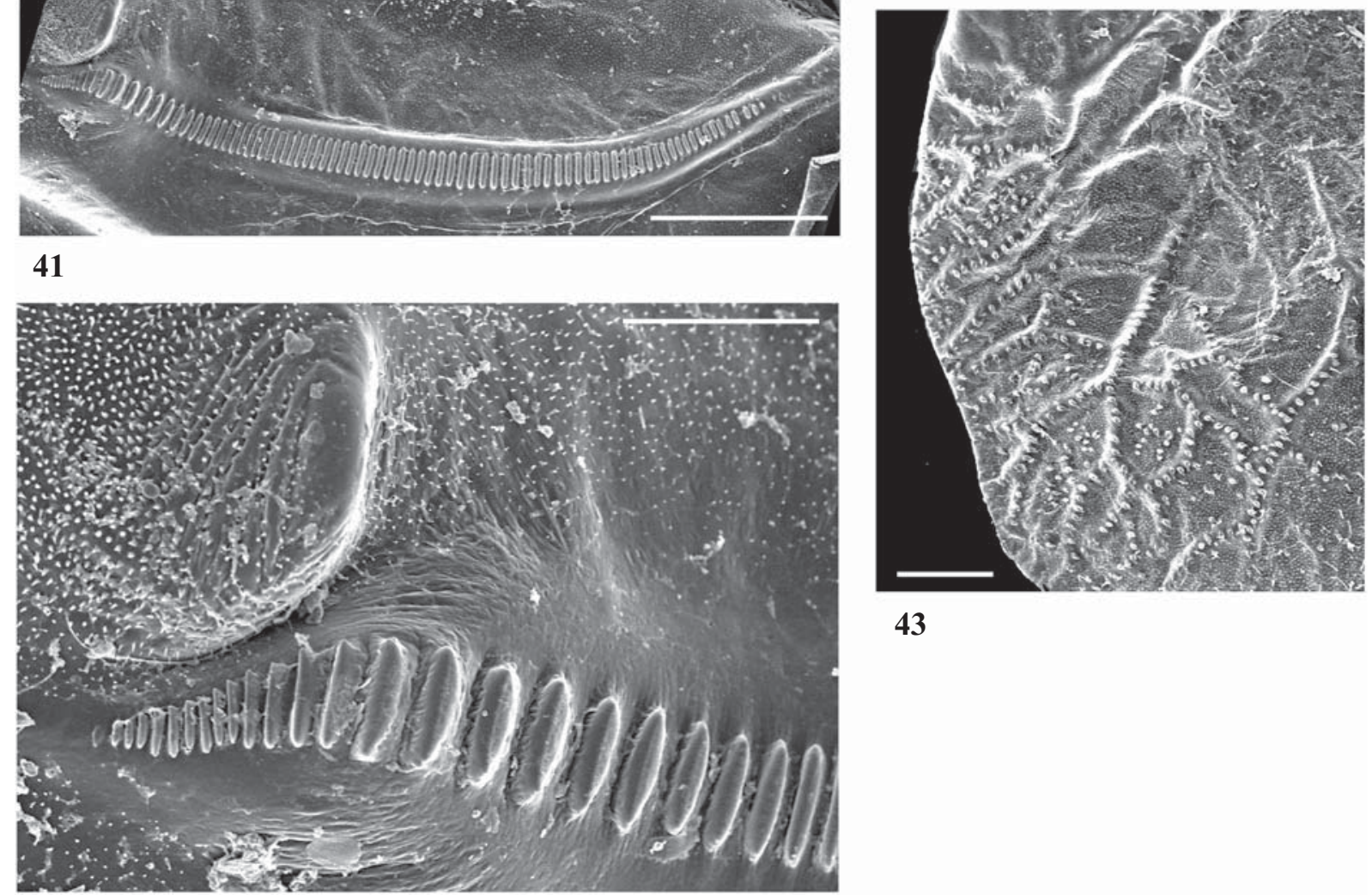

43

42

Figs 41-43. Polysarcus zacharovi: 41-42 - male stridulatory file; 43 - fragment of the lower female tegmen with stridulatory teeth on the medial veins. Scale bars: $41-800 \mu \mathrm{m} ; 42-200 \mu \mathrm{m} ; 43-500 \mu \mathrm{m}$.

Рис. 41-43. Polysarcus zacharovi: 41-42 - стридуляционная жилка самца; 43 - фрагмент нижнего надкрылья самки с зубчиками на медиальных жилках. Масштаб: 41 - 800 мкм; $42-200$ мкм; $43-500$ мкм. 
from south European populations [Heller, 1988]: calling signal of $P$. denticauda consists of three phases too and the pulses are of the same structure. However pulses in both phases as well as inside of each phase have approximately equal duration and in the first part of the song they have very regular repetition rate. Males of another species ( $P$. scutatus (Brunner von Wattenwyl, $1882)$ ) distributed in southern Europe and Northern

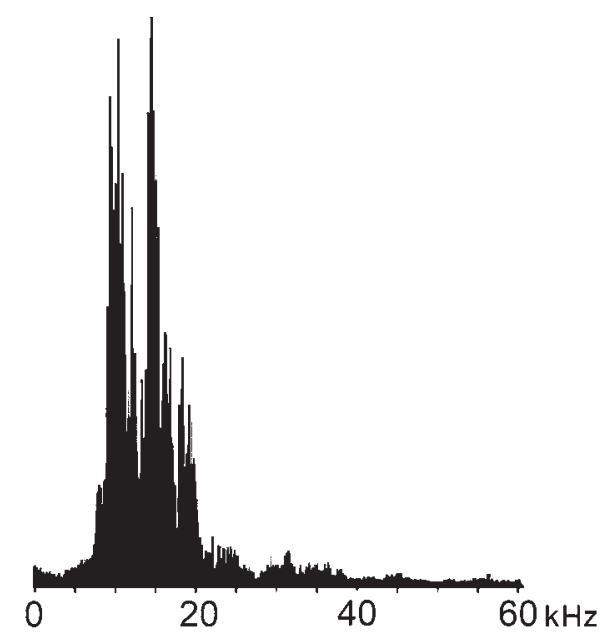

\section{Whitherwhy}

37
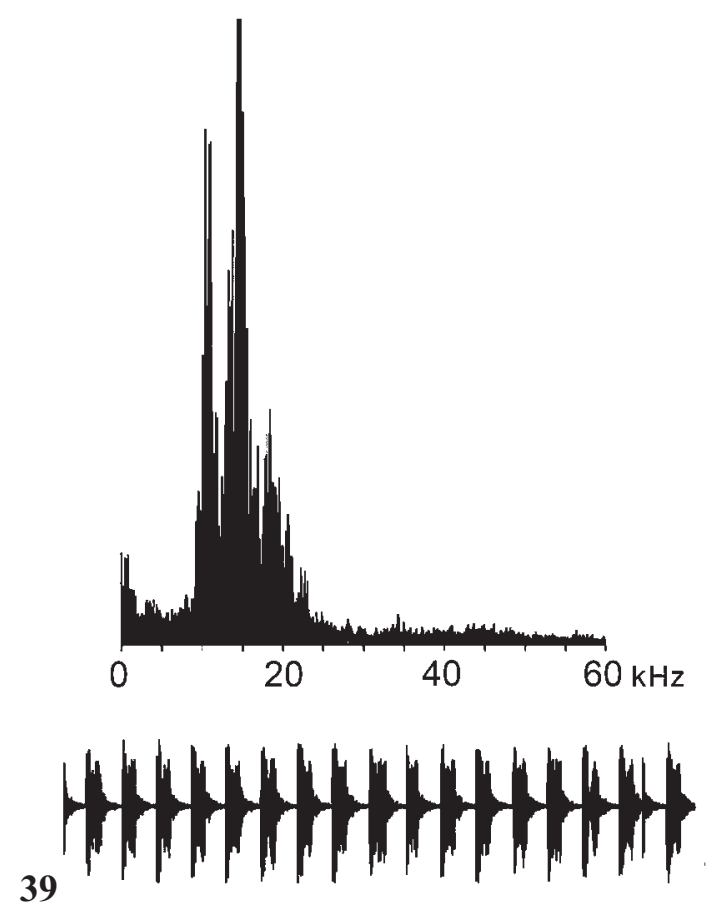

Africa produce calling song consisting of the $1^{\text {st }}$ and the $2^{\text {nd }}$ phases only [Heller, 1988]. It is known that females of $P$. denticauda can produce similar but less loud complicated song [Faber, 1957].

Besides calling song males $P$. zacharovi produce protest sounds (Figs 34-36). These are trills consisting of uniform pulses with rate $7.5 \pm 0.1 \mathrm{~s}^{-1}(\mathrm{SD}=0.4)$. Duration of the pulses is $102.9 \pm 1.4 \mathrm{~ms}(\mathrm{SD}=7.1)$, intervals
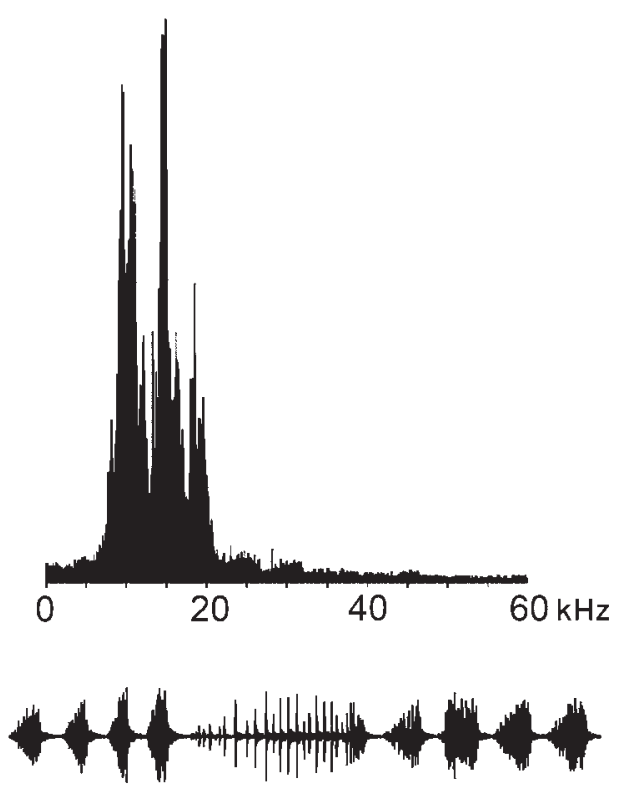

38
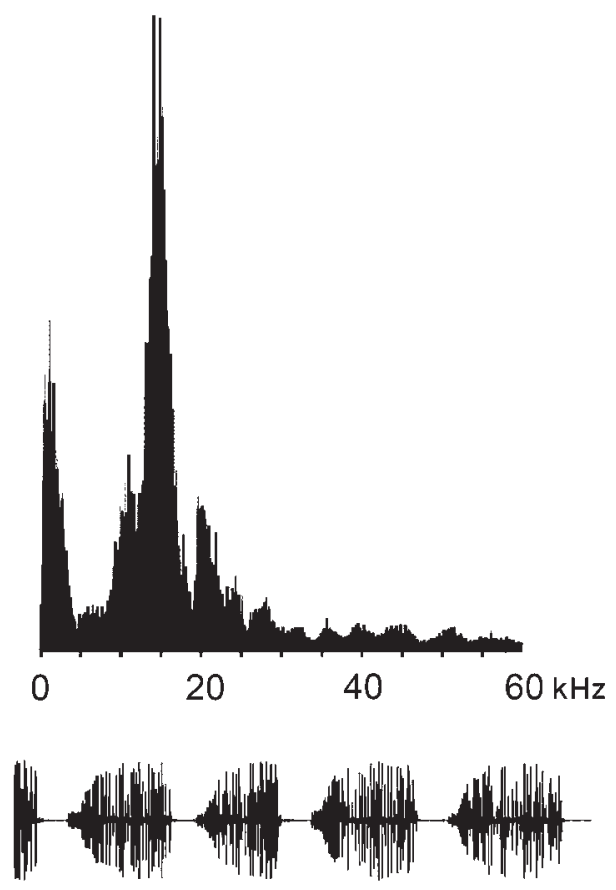

Figs 37-40. Frequency spectra of different parts of calling song (37-39) and protest sounds (40) of male Polysarcus zacharovi. Below different fragments of the songs.

Рис. 37-40. Амплитудно-частотные спектры разных частей призывного сигнала самца (37-39) и звуков протеста (40). Внизу различные фрагменты сигнала. 
between them are $29.6 \pm 0.4 \mathrm{~ms}$ long $(\mathrm{SD}=2.1)$. Duration of these trills depends of disturbance level of the insect.

Frequency spectra of three phases of the calling song are very similar: main components lie between 10 and $20 \mathrm{kHz}$. Dominant frequencies are at 10 and $15 \mathrm{kHz}$ (Figs 37-39). Spectrum of protest sounds distinguishes from the calling song one by absence of the peak at 10 kHz (Fig. 40).

Weakly curved male stridulatory file is shown in Fig. 41. The medial teeth have less density and lie on a concavity. Near there is a big tooth-like structure (Fig. 42). Perhaps it is used in producing of the very loud $3^{\text {rd }}$ phase of the song.

Structure of female sound apparatus is similar to the one of another Odonturinae species. Medial parts of a veins on the dorsal surface of the right (lower) tegmen bear teeth (Fig. 43), plectrum lies on the inner surface of the left (upper) tegmen.

\section{Conclusions}

The comparison of songs of investigated wide spreading species with known data (op. cit.) concerning other palaearctic phaneropterine bush-crickets shows that temporal characters and frequency spectra in the songs of $B$. constrictus and L. albovittata are very similar in different part of distribution area, i.e. its variability is very low. The differentiation of a male song pattern in Leptophyes is connected with speed of tegmina closing movement. Additional sound units are the result of pause(s) before final closing of the wings. Appearance of the final click in L. albovittata, L. laticauda and L. punctatissima is optional and we consider that such state of the song is plesiomorphic. However in L. laticauda and $L$. discoidalis click or pulses are the result of separate wing movements [Heller, 1988]. The calling song of $E$. iris represented temporal pattern owned Barbitistes spp. and L. discoidalis. Thus different temporal patterns apparently evolved in different genera repeatedly and independently. Most complicated song in palaearctic Phaneropterinae is produced by Polysarcus spp. It is interesting that temporal characters and frequency spectra in congenerics are different but the pattern of the male calling song is very similar in all investigated species.

AKNOWLEDGEMENTS. Authors are very grateful to A.Benediktov and D.Tishechkin for collecting and deliver- ing living insects of some species. Proceeding of this paper is supported by Russian Science Foundation project No. 1450-00029.

\section{Literature}

Avakian G.D. 1981. [Tettigoniids (Tettigonioidea)] // Fauna Armyanskoy SSR. Nasekomye pryamokrylye. Erevan: Izdatelstvo AN Arm.SSR. 118 pp. [In Russian].

Faber A. 1957. Über parallele Abänderungen bei Lautäusserungen von Grylliden mit Bemerkungen zur Frage der Phylogenie von Stridulationsformen // Stuttg. Beitr. Naturk. Bd.2. S.1-10.

Chobanov D.P., Grzywacz B., Iorgu I.S., Çiplak B., Ilieva M.B., Warchałowska-Sliwa E. 2013. Review of the Balkan Isophya (Orthoptera: Phaneropteridae) with particular emphasis on the Isophya modesta group and remarks on the systematics of the genus based on morphological and acoustic data // Zootaxa. Vol.3658. P.1-81.

Heller K.-G. 1988. Bioakustik der europaeischen Laubheuschrecken. Weikersheim: Verlag Josef Margraf. $358 \mathrm{~S}$.

Heller K.-G. 1990. Evolution of song pattern in East Mediterranean Phaneropterinae // The Tettigoniidae: biology, systematics and evolution // W.J. Bailey \& D.C.F. Rentz (eds.). Berlin: Crawford House Press. P.130-151.

Heller K.-G., Orci K.M., Grein G., Ingrisch S. 2004. The Isophya species of Central and Western Europe (Orthoptera: Tettigonioidea: Phaneropteridae) // Tijdschrift voor Entomogie. Vol.147. P.237-258

Kleukers R.M.J.C., Odé B., Fontana P. 2010 Two new cryptic Leptophyes species from southern Italy (Orthoptera: Tettigoniidae)// Zootaxa. Vol.2506. P.26-42.

Korsunovskaya O. 2015. Sound communication and recognition of the calling song in bush-cricket Isophya gracilis Mir. (Orthoptera, Phaneropteridae) // Bull. Moscow Soc. Nat. Biol. Ser. Vol.120. No.4. P.26-30.

Ragge D.R., Reynolds W.J. 1998. The songs of the grasshoppers and crickets of Western Europe. Martins etc.: Harley Books. 591 pp.

Sevgili H., Caglar S.S., Saglam I.K. 2010. Re-evaluation of the genus Phonochorion (Orthoptera: Tettigoniidae: Phaneropterinae) // Eur. J. Entomol. Vol.107. P.631-645

Stumpner A., Meyer S. 2001. Songs and the function of song elements in four duetting bushcricket species (Ensifera, Phaneropteridae, Barbitistes) // J. Insect Beh. Vol.14. No.4. P.511534.

Zhantiev R.D. 1981. [Bioacoustics of insects]. Moscow: Moscow University Press. 256 pp. [in Russian].

Zhantiev R.D., Dubrovin N.N. 1977. Sound communication in the genus Isophya Br.-W. (Orthoptera, Tettigoniidae)//Zool. Zhurn. Vol.56. P.38- 25 [in Russian, with English summary].

Zhantiev R.D., Korsunovskaya O.S. 1986. [Sound communication in bush crickets (Tettigoniidae, Phaneropterinae) of the European Part of the USSR] // Zool. Zhurn. Vol.65. P.1151-1163 [in Russian, with English summary].

Zhantiev R.D., Korsunovskaya O.S. 1990. Sound communication of Phaneropteridae (Orthoptera) // Sensory system and communication in Arthropods. Advances in life sciences. Basel etc.: Birkhauser Verlag. P.403-406. 